\title{
Workplace regimes in Sino-Mozambican construction projects: Resentment and tension in a divided workplace
}

Ulrikke Wethal $^{1}$

Centre for Development and the Environment,

University of Oslo

P.O. 1116 Blindern,

0317 OSLO

+4722858951/u.b.wethal@sum.uio.no

\footnotetext{
${ }^{1}$ I would like to thank my research assistant Sérgio António Cossa for crucial help with the data collection in Maputo. I would also like to thank Hege Merete Knutsen, Desmond McNeill, Dan Banik, Arve Hansen, SUM Research School, and my anonymous reviewers for valuable comments.
} 


\begin{abstract}
Based on a qualitative study of Chinese-led construction projects in Mozambique, the article explores how Chinese engagement in the construction sector affects workplace regimes. The study addresses the following set of questions: What characterises the workplace regimes of Sino-Mozambican workplaces, and why do the workplace regimes give rise to resentment and tension amongst the Mozambican workers? Furthermore, how is labour agency constrained or enabled within these workplace regimes? The data reveals that the Chinese companies are granted great freedom to develop workplace regimes as they see fit, characterised by functional flexibility, low pay, and few benefits. Furthermore, the creation of a divided Sino-Mozambican workplace, with separate workplace regimes for the Chinese and the Mozambican workers, exacerbates resentment amongst Mozambican workers and prevents social relationships across nationalities from forming. The Mozambican workers employ multiple strategies to express their discontent, but labour agency is constrained by weak national institutional support, and lack of alternative employment opportunities in the local labour market.
\end{abstract}

Keywords: Workplace regime, resentment, labour agency, Mozambique, China

\title{
Introduction
}

On January $4^{\text {th }} 2014,230$ Mozambican workers from the Chinese-led construction project Estrada Circular (Maputo Ring Road) initiated a strike. According to local media, ${ }^{1}$ the workers were protesting against a missing New Year bonus, dismissals without just cause, physical assaults, lack of written work contracts, and poor health and safety conditions. The Mozambican workers, however, were more concerned with the initial trigger in their narrative of the strike:

It started when a black boss hit a driver and we saw that he was already becoming like the Chinese, having the same behaviour as the Chinese, and turning against his real brothers. Therefore, we decided to do the strike. ${ }^{2}$ (Group interview, Mozambican workers, 16.01.14)

The distinction between these two descriptions reveals that the workers find their resentment originating in complex issues of segregation and distrust. Several interviews with the Mozambican workers illustrate how they categorise certain behaviour as Chinese and the implicit expectation amongst them to support each other - against the Chinese. There is a very vivid $u s$ vs them mentality in the Sino-Mozambican workplace, leading to unresolved 
tension between the two nationalities working side by side on construction projects in the capital area of Mozambique.

This article will use the analytical concepts of workplace regimes and labour agency to explore how Chinese engagement in the construction sector in Mozambique affects the workplaces. First, the article explores why the workplace regimes created give rise to resentment and tension, and second, examines how labour agency of the Mozambican workers is constrained or enabled within these workplace regimes. The study draws on the labour agency approach in labour geography, and seeks to understand the workplace and labour agency from the Mozambican workers' perspective.

There is a growing literature on Chinese business practices in Africa (e.g., Baah and Jauch 2009; Lee 2009; HRW 2011). However much is still unknown about how local populations receive and negotiate Chinese company practices. The bulk of research on China in Africa has based its analyses on macro-data of trade, investments and aid flows, but few qualitative, fieldwork-based studies have been conducted (Braütigam 2008; Mohan and Power 2009). Ample attention has been given to speculations about the Chinese agenda, strategies and motives for operating in Africa, as well as attempts to unpack links between the Chinese state and Chinese state-owned enterprises (SOEs) (Alden and Davies 2006; Lee 2006; Meidan 2006; Kragelund 2009). Although several scholars have contributed to understanding working conditions in Sino-African workplaces (see, e.g., Giese and Thiel 2012; Lee 2009; Nielsen 2014), these studies have not analysed workplace regimes. The workplace regime approach provides a useful framework for examining the interplay between the various elements that create conditions in a specific workplace, and gives a basis for understanding resentment in the workplace.

African governments appear eager to develop relations with China, and many developing countries today seem to envy China's outstanding economic achievements. China has become Africa's largest trading partner, and two-way trade between China and Africa reached 166 billion USD in 2011, up from 2 billion USD in 1999 (Cottle 2014). Moreover, China has obtained growing influence on the continent, with its most visible imprint being the many large-scale infrastructure projects and prestige projects in construction. China has become active in the construction industry in almost every African economy (CCS 2006), making this industry a relevant point of departure when exploring Sino-African relations. During the late 1990s, the Chinese government saw the need to make the SOEs more self-reliant and globally 
competitive and urged them to invest and operate abroad. In 2001, the strategy was formalised as China's 'Going Out' or 'Going Global' strategy (HRW 2011). The state assisted companies in establishing branches overseas and encouraged them to enter new markets. Through bilateral agreements, China provides African states with loans that often guarantee Chinese SOEs contractor rights and ensure the use of Chinese goods in development projects (Robertson and Corkin 2011). In parallel, Chinese SOEs and private companies are establishing themselves in African markets, winning national and international tenders in construction. The competitive state of China's domestic construction market has also made the government use various financing mechanisms for infrastructure overseas as a way to boost their own construction sector ${ }^{3}$. Over 2000 Chinese State Owned Companies (SOE's) now have businesses in Africa, with a market share larger than that of France, Italy and US combined. Their main advantage in African markets tends to be explained with competitive pricing, where Chinese companies often submit bids three quarters less of Western firms (Cottle 2014). Chinese companies also have a habit of bringing their own work crew rather than employing local workers (Wang and Flam 2007; Afrodad 2008), although some researchers suggest that the use of Chinese labour crews is exaggerated (e.g., Vines 2007; Mohan and Lampert 2013). In any respect, the increasing presence of Chinese firms in the African construction sector illustrates the importance of understanding how this engagement influences workers and workplaces.

Mozambique has had one of the fastest growth rates of trade with China experienced by any single nation (Robinson 2012). The Mozambican government has been very open to Chinese involvement, mainly in construction and agriculture, but also increasingly in extractive industries. China is now one of the country's largest investors. ${ }^{4}$ China's interest and expertise in supporting construction and infrastructure projects has made it a particularly appealing partner for Mozambique, especially since much of Mozambique's physical infrastructure was destroyed during the civil war ending in 1992 . More than 30 Chinese construction companies have established themselves in Maputo, outbidding South African and other foreign companies in national and international tenders (Alden, Chichava and Roque 2014), or working on projects financed by Chinese financial institutions.

Despite impressive growth rates with an average of 7 percent GDP growth annually over the last decades (Dibben 2010; IMF 2011), the Mozambican economy is still characterised by a strong dependence on foreign capital. The country's development strategy has focused on attracting foreign investments that should yield economic growth, and eventually trickle 
(Magnusson, Knutsen, and Endresen 2010). down to benefit poorer segments of the population (Afrodad 2008; Wethal 2015). According to Nielsen (2014), the Mozambican government has given China 'a seemingly unlimited economic room for manoeuvre' (68). Apparently, the governing elite perceive Chinese activities as a potential advantage and diversity against traditional partners, after decades of relying on aid from the Western donor community (Alden, Chichava and Roque 2014). However, while the government continue to welcome Chinese engagement, tension is emerging in various areas of Sino-Mozambican cooperation, especially amongst Mozambican workers in Chinese-led projects.

The strike mentioned above provides a starting point for discussing this tension. I will first discuss the two theoretical concepts on which the analysis is based, and which form the analytical framework: workplace regimes and labour agency. I will then elaborate on the methods for data collection and analysis. I explore the workplace regimes created in SinoMozambican workplaces and examine tension and resentment amongst the Mozambican workers. Furthermore, I discuss how agency of Mozambican labour is constrained or enabled by the workplace regime. The concluding section summarises the main findings.

\section{The workplace in theory and practice}

Every workplace is created through a web of policies and practices, and can be studied at different analytical and geographical levels. Moreover, the globalisation of production has led to a complex set-up that requires an understanding of the 'spatial politics of production' (Pun and Yu 2008). Michael Burawoy's The Politics of Production (1985) has been quite influential in guiding analyses of capital-labour relations. Burawoy focused on what he called 'factory regimes' and divided these regimes into several ideal-types to capture different power relations between labour, capital and the state (see, e.g., Peck 1996; Knutsen and Hansson 2010).

The literature tends to use factory regimes, labour regimes, and workplace regimes interchangeably (see Magnusson, Knutsen, and Endresen 2010; Dokka, Knutsen and Endresen 2015). For example, while Burawoy (1985) use factory regimes as an analytical abstraction, Nichols et al. (2004) have operationalised the same concept in order to describe specific workplaces. The general approach of the operationalization of Nichols et al. (2004) invites analyses of workplaces beyond the factory, but their use of the concept factory 
regimes limits the analysis semantically. I find the term workplace regime preferable in this analysis because the objective is to study processes in concrete workplaces.

Analytically, a workplace regime entails two interlinked levels of politics: the organization of the workplace and the politics of production (Burawoy 1985; Peck 1996). The organization of the workplace, or the first level, refers to the technical and social organisation of the labour process. Nichols et al. (2004) identify three issues to study in order to practically identify and describe the organisation of a workplace: (1) Labour control issues are management methods such as autonomy vs control, empowerment of labour vs intensification of work, fear vs commitment, and working conditions, cultural control, and teamwork. (2) Material support issues include both wages and non-main wage material support. The composition of wages (basic/variable part) and wage level in relation to the local labour market are both central here. (3) Contract issues describe whether workers hold internal or external contracts for permanent, temporary, or part-time work. Different types of contracts can affect workers' status: For example permanent workers may be treated differently than temporary workers. The links between labour control issues, material support issues, and contract issues are also central to how workers perceive their own working conditions such as the working environment and terms and conditions of employment.

The second level of politics that make up a workplace regime is the 'politics of production', or the political apparatus of production and the institutions that regulate and shape workplace practices (Burawoy 1985; Peck 1996). Workplace regimes do not evolve in isolation, but rather develop under the influence of local, national, and global regulations and institutions (Magnusson, Knutsen, and Endresen 2010). This second level of issues will thus be analysed by highlighting how the state, market, and collective organisation in Mozambique affect practices in the Sino-Mozambican workplace. The interplay between these two levels of politics is central in explaining the nature of workplace regimes.

\section{Labour agency under contemporary globalisation}

Castree et al. $(2004,159)$ define agency as 'the capacity possessed by individuals and groups to act for their own benefit or for the well-being of others'. In this article, understanding agency means understanding how the Mozambican workers, both as a group and individually, 'play a role in seeking, and obtaining, incremental and sometimes highly significant changes in microspaces of work and living' (Rogaly 2009, 11). 
During the 1990s, labour geographers introduced the notion of labour agency to the agenda as an alternative to the view of workers as passive victims of the workings of capitalism (Cumbers, Nativel and Routledge 2008; Carswell and de Neve 2013). Such an approach focuses on how workers themselves may attempt to '... shape the landscape of capitalism to their own advantage' (Herod 2001, 4). Of main importance is to make workers' experiences and actions central to the analyses of capitalism, hence, understanding the geography of work and capitalism from their perspective (Herod 2001). This approach has informed my study of Sino-Mozambican workplaces.

While labour agency can be understood as: 'strategies that shift the capitalist status quo in favour of workers, even if only temporarily' (Coe and Jordhus-Lier 2011, 216), such strategies do not necessarily challenge the hierarchy of the capitalist system per se. Rather, workers seek to secure a better distribution of gains or better their own position within the system. Furthermore, the discussion on labour agency involves a certain discrepancy between what strategies attempt to do and what they actually accomplish. Agency can be constrained by various social structures and across socio-geographical spheres. Of importance is how the institutional framework - state, market and collective organisation - constrains or enables workers' agency. This article explores the question of labour agency by illustrating how Mozambican workers react to the Sino-Mozambican workplace regime, and whether and how they seek to change their role in it.

Labour geographers tend to approach agency along the lines of space, scale and place in order to grasp the complex conditions that affect the strength of workers' agency (Coe and JordhusLier 2011). Space refers to how workers' position within the geographies of capitalism affects the impact of their actions. Scale refers to the level at which negotiations occur, for whom decisions are made, or across what territories solidarity is pursued. Scale places focus on the crucial role of regulatory institutions conditioning working life. Both space and scale contribute in shaping place. Features of place determine the mobility of workers, their ability to move between workplaces, affected by workers' attachments and responsibilities in place. Space, scale and place are used to understand the potentials for and limitations to workers' agency in the Sino-Mozambican workplace.

Labour agency entails both workers' collective struggles and individual struggles. Individual struggles, however, have frequently been overlooked compared to collectively organised political strategies (Coe and Jordhus-Lier 2011). In this article, agency will be analysed with 
reference to both collectively organised political strategies and by individual worker's responses to improve working conditions. I use the concepts of exit, voice, loyalty, and neglect in order to explore how workers' response strategies are linked to agency. The first three concepts can be traced back to Hirschman (1970), in his attempt to understand responses to decline in firms, organisations, or states. His approach was later applied to workers' response to job dissatisfaction, and neglect was included as a fourth category (e.g., Farrell 1983; Rusbult et al. 1988; Farrell and Rusbult 1992). Exit and voice are active response strategies. Exit refers to requesting a transfer, searching for a different job, or simply thinking about quitting. Voice describes constructive actions workers take to improve working conditions such as discussing problems with superiors or colleagues, suggesting solutions, seeking help from outside, or by whistle blowing. Loyalty and neglect are passive responses, when workers loyally wait and hope for an improvement while trusting the organization to do the right thing, or passively allowing working conditions to deteriorate due to reduced effort or interest.

\section{Methods and data}

The theoretical concepts outlined in the sections above form the analytical framework that has guided this analysis of Sino-Mozambican workplaces. I analyse labour agency by examining how the workers respond to the workplace regime. Workers' response strategies can be understood as a concretisation of labour agency within a particular workplace. Workplace regimes may enable or constrain labour agency, and labour agency may affect how workplace regimes are organised. Consequences of workers' response strategies may alter the workplace regimes created, and add to workers' agency (i.e. when a strike leads to alterations in working conditions). The analysis is concerned with how workplace regimes influence agency and how agency influences workplace regimes. The broader institutional framework affects both workplace regimes and response strategies, through the state (laws, regulations, capacity), the market (competition, labour market) and collective bargaining (strength and capacity of trade unions).

The analysis of the Sino-Mozambican workplaces is based on data from fieldwork conducted in Maputo, Mozambique, from May to September, 2013. I examined three projects led by Chinese companies in road works, water supply, and housing. Two of the Chinese companies were state-owned; the third was a joint venture between a Chinese state-owned company and 
a Mozambican directorate which together formed a private company. I have anonymised the Chinese companies in this article. Contrary to the popular depiction of the 'Chinese way' as bringing labour from China, Mozambicans made up more than $3 / 4$ of the workers in the workplaces in this study.

Together with a research assistant, I collected data through observation and 35 semistructured interviews. Observation took place on the construction sites and included observations of work routines, interaction, cooperation and communication between the Mozambican workers and their Chinese superiors. We also accessed documentation such as pay checks, contracts and time sheets. We conducted nine semi-structured interviews (group and individual) with Mozambican workers. Three supplementary interviews with workers were conducted in $2014 .^{5}$ Most of these interviews took place outside construction sites during lunch breaks, and were generally not arranged in advance. We conducted the remaining interviews with Chinese company administration and engineers (eight interviews), Mozambican ministries and governmental bodies linked to the projects (seven interviews), inspection companies (three interviews), and trade unions, business associations, and related organisations (five interviews). These interviews were arranged in advance, and took place in formal settings. The duration of the interviews varied from 30 minutes to 1,5 hours, depending on the informants' schedule. I audiotaped and later transcribed most of the interviews, and documented the remaining with detailed interview notes. ${ }^{6}$

All interview transcripts, interview notes, and observational notes were organised and coded in the NVivo software for qualitative analysis. The coding captured the operationalisation of Nichols et al (2004) for identifying workplace regimes; labour control issues, material issues and contract issues, and codes such as negotiation, communication, resistance and conflict identified agency. In the first round of coding, I found broader themes that recurred in the workers' responses, and re-coded the data with codes such as commitment, divisions or respect. As such, the analytical framework was developed abductively, through an interplay between deductive and inductive approaches (Thagaard 2009).

\section{The Sino-Mozambican workplace regimes}

What can we make of the workplace regimes under study? What happens to Chinese company practice in a Mozambican context, and what do Chinese companies bring to the workplaces that give rise to contestation and tension? A workplace regime is created through 
a web of policies and practices: place-specific characteristics influence how the labour strategies of companies are 'shaped by the role of the state in reproduction of labour, the relation between external and internal labour markets, dynamics of local political movements, and structure of household division of labour' (Peck 1996, 138). This suggests that 'exporting' Chinese workplace practices to Mozambique is not possible, as labour market conditions and the macro-politics of the state in Mozambique differ from labour market conditions and macro-politics in China. The Mozambican government has mostly been concerned with formulating an industrial policy that gives direction and incentives without interfering in business decisions. According to Castel-Branco (2001, 162), the policy 'announces government intentions to the business community and avoids action and intervention by the state in any specific issue.' The limited capacity of the government has also resulted in the weak and uneven enforcement of labour regulations (Webster and Wood 2005). Despite both high union density and relatively strict labour regulations, there is very little evidence that unions have been effective in supporting workers' interests at the company level (Webster et al. 2006). Moreover, while Chinese companies' participation in international tenders launched by the Mozambican government or the World Bank is thought to weaken their bargaining position and thus, their ability to impose certain labour requirements (Roque 2009), the data suggest that the Chinese companies enjoy great freedom in formulating labour strategies. While problematic working conditions appear to be 'common knowledge' amongst Mozambican government officials, they emphasize the number of workers employed rather than the quality of their working conditions. As a result, Chinese companies seem to be able to develop workplace regimes as they see fit.

The data suggests there are large similarities in workplace regimes across the three construction projects in this study. Thus, one may speak of one workplace regime for the Mozambican workers, although this analysis draws on data from three different workplaces. The following sections are organised along Nichols et al.'s (2004) categorisation of labour control issues, material support issues, and contract issues. The analysis shows that the SinoMozambican workplaces are characterised by strong divisions, both spatially and metaphorically. This signifies the existence of two workplace regimes in one workplace, one regime for the Chinese, and another for the Mozambicans. 


\section{Labour control issues}

There are various ways for companies to exercise control over labour. The literature on workplace regimes in China highlights the use of dormitories for spatial control, where the employer can control the whereabouts of the workers at all times. The dormitory workplace regime is often thought of as a distinct Chinese labour practice (Pun and Smith 2007; Pun and $\mathrm{Yu}$ 2008), found in many different types of production. Construction is no exception, and construction workers typically live in dormitories in construction projects in China (Tang 2014). In construction projects in Maputo, however, the dormitories are given a very different meaning. They are reserved for the Chinese workers, who live in a foreign place, do not understand the language, or have time to familiarise themselves with the local community. Chinese project managers explain that the dormitory practice for Chinese workers in Mozambique is a useful way of protecting the workers and give them a sense of togetherness and social belonging. Safety and facilitation of social life replace the issue of control in the Mozambican context (Interview, Chinese project manager, 19.03.13). However, with this changing significance of the workers' dormitories, they have rather come to resemble gated communities, with high fences, 'keep out' signs, and barbed wire.

The Mozambican workers arrive at the construction sites each morning from their homes scattered in and around the capital area. Mozambican workers are not permitted to use the dormitories even though many of them are migrant workers. Apparently, the Chinese superiors see little need to control the Mozambican workers outside the workplace. This could be linked to the fact that the Chinese companies do not consider themselves as responsible for Mozambican workers. They turn to a Mozambican labour office should they need more or other workers. To separate labour from company management is a common practice in Chinese construction companies in China, where the main contractor tend to subcontract the responsibility of labour to smaller companies (Ngai and Huilin 2010). This spatial separation of workers also occurs in other social settings, such as lunch. Here, Chinese employees have food prepared for them at the project site, while Mozambicans bring food from home or eat at the nearest barraca (simple kiosk). The idea of eating together, either the same food or physically sitting together, seems farfetched. The ways in which Chinese and Mozambicans are physically divided in the workplace discourages socialisation between the two groups, creating divisions between the two nationalities. 
The divided workplace continues in the organization of work tasks. Mozambican workers perform low-skilled tasks, and are excluded from management and project planning. The work is organised in teams, which according to Nichols et al (2004) could elicit either commitment or control. In the Sino-Mozambican workplaces, the organisation of teams seems to contribute to the control of workers. Each team consists of one Chinese superior and between five and ten Mozambican workers, often with different combinations of workers each day. The superior would mainly show them what to do, often formulating tasks in terms of numerical goals such as the number of bricks to lay, or the specific area to be covered or dug open. Machine operators would often work in teams of two with one Chinese superior and one Mozambican operator, leading to a higher degree of commitment and transfer of skills. However, the larger teams generally create a low autonomy for the Mozambican workers.

The Mozambican workers express great discontent about the functional flexibility strategies initiated by the Chinese construction companies. Functional flexibility refers to workers performing multiple tasks, allowing management 'to move workers around jobs and tasks as the need calls' (Dyer 1998, 228). According to Mozambican law, all workers should have contracts which specify their positon (ACIC 2011), and the workers interviewed had all been hired with a specific position. In practice, however, the company disregards these work categories and the specification of positions:

There are various sectors, but a mechanic can be sent for construction, a driver can be sent for construction, or for mechanics. The mechanic can also be sent to the pumps. Because of this, every day when you arrive here for work, you just wait for your boss to see you and say; today you go to site $\mathrm{x}$. And you have to go to that site because he is the one that signs the timesheet. (Group interview, Mozambican workers, 17.05.2013)

The Mozambican workers express both humiliation and a lack of motivation at the Chinese disregard for work categories. It deprives them of pride and reputation they have obtained through previous jobs, and they feel as if they are taking a step back instead of advancing:

We are all equal. We are all servants. If you're an operator, you have the position of a servant, if you're a driver, same thing. The next day you stand with a shovel. (Group interview, Mozambican workers, 17.05.13) 
The workers explain that even if they feel like they are improving their competence in a specific role, they may be set to do something completely different the next day. The aspects above lead to a lack of autonomy for the Mozambican workers, being at the mercy of their superiors. From the Chinese point of view, the functional flexibility is a strategic choice. The Chinese workers primarily perform technical tasks, and large construction projects have great amounts of heavy bodywork, requiring minimal skills. Mozambican law prevents Chinese companies from bringing more than a given number of Chinese nationals to the projects, and as a result, local labour is mainly doing the physical and heavy work.

For Mozambican workers, functional flexibility is also associated with the fear of being dismissed, by intensifying the feeling of being replaceable. Colleagues have been fired for no reason and Chinese supervisors threaten workers with dismissal, regardless of how long they have worked for the company:

It is normal here that they tell you to go home, without motive. It doesn't interest them if the contract is one year - just go home. Done. (Interview, Mozambican worker, 17.05.13).

The sentiment in the excerpt above corresponds with Lee's (1999) description of workplace regimes in China where superiors may respond to complaints with the threat 'you can leave if you don't agree.' It also echoes more recent cases of Chinese companies working in other African countries (Baah and Jauch 2009; HRW 2011). In combination with the lack of viable ways to communicate with superiors, the Mozambican workers experience a high degree of job insecurity, which enhances control on behalf of the Chinese management. Job security is generally not high in countries with large informal labour markets and high unemployment rates, such as Mozambique. However, the challenges related to communication prevents workers from understanding why they are fired, which could make this a more important source for tension in Sino-Mozambican workplace regimes.

The Mozambican workers talk about themselves and the Chinese as two strictly separate groups: 'We do not have any relationship, neither professional nor friendly' (Group interview 1, Mozambican workers, 17.05.13). This underlines the belief that all the Chinese are bosses in the eyes of the Mozambican workers: 
Everyone who works here is Mozambican. The evil Chinese, the one that comes from China, is head of the group. He only comes to rule and not to work. (Group interview, Mozambican workers, 03.06.13)

Interviews with Chinese management and engineers reveal that several of the Chinese workers have the same amount of skills as the Mozambicans and, like the Mozambican workers, are under the supervision of other superiors. However, the Mozambican workers interpret the division of labour differently. With the lack of common language and limited social relationships, Mozambican workers easily conflate the role of Chinese workers with Chinese management, creating a feeling of constantly being watched and controlled by superiors. In one of the projects, for example, there were four different subcontractors, three Chinese and one Mozambican. However, the workers did not know which contractor employed them, only that their immediate superior was Chinese (Group interviews, Mozambican workers, 05.06.13, 01.08.13). The Mozambican workers' understanding of the division of labour on the construction sites illustrates the distance between the workers and their Chinese superiors. This is in stark contrast to the sentiment expressed by Zambian miners working with Chinese companies in Zambia. In Lee's (2009) study, the workers tended to appreciate the Chinese work style because the Chinese workers would 'get dirty' and execute the same tasks as them, minimising the distance between the two groups (Lee 2009). Such a feeling of equality is not present in the Sino-Mozambican workplace.

According to an extensive study of employee relations in Mozambican companies by Webster and Wood (2005), ${ }^{7}$ the Mozambican workplace is characterised by a culture of workplace authoritarianism. Job coercion, poor pay and working conditions are the norm, with low long-term investment in the workforce. However, a certain social contract between the employer and the employee seem to compensate for these conditions (Webster and Wood 2005; Webster, Wood and Brookes 2006; Wood 2011). The Mozambican managers in the study rarely make use of rigid sets of rules, but tend to have relatively good informal relationships with the workers. Recruitment is normally based on personal networks, leading to a close relationship between workers and managers. Consequently, the managers are willing to adjust terms and conditions in response to individual workers' immediate needs by, for example, advancing payment or granting leave on short notice. In the Sino-Mozambican workplaces, on the other hand, there is no such social contract. The Mozambican workers have close to no contact with management: 'I cannot say anything about our Chinese boss here...I don't know him'. (Group interview, Mozambican workers, 17.05.13) The Chinese 
superiors treat Mozambican workers collectively as a group, with no understanding of personal issues or needs.

Underlying nearly all the issues mentioned above is the lack of viable ways to communicate. The Mozambican workers spoke Portuguese, in addition to one or more local languages, and very few spoke any English. The Chinese management spoke English in addition to their mother tongue, but this was not common amongst the Chinese workers that supervised the Mozambicans. In day-to-day work routines, communication was based on a few words in English or Portuguese, signs, and body language. By exploring the three workplaces in question, it becomes clear that the lack of viable ways to communicate is not just a challenge for finding the words in order to get the job done, but so many other elements also end up 'lost in translation'. Lack of communication makes it hard to create relationships in the workplace across nationalities. It strengthens the already strong divisions between the workplace regimes of the two groups, and is a source for great confusion. Furthermore, lack of communication hampers an already low degree of skill transfer between the Chinese and Mozambican workers. Because of the problematic communication between the Chinese and the Mozambicans, instructions tend to come out as orders, reinforcing the distance and barriers between the two groups. Lack of communication and relationship between Chinese and Mozambican workers create little basis for trust. When the Mozambican workers struggle to explain themselves both about personal issues or difficulties at work, the Chinese perceive them as unreliable:

They immediately come running speaking in Chinese that he [the Mozambican] was there to steal. They do not rush to know what is up, and when you want to explain they do not want to listen at all. They only speak together, alone, already saying that he stole, and when you want to make them understand, nobody wants to know, no Chinese wants to understand. (Group interview, Mozambican workers, 17.05.13)

Such problematic language barriers are also found in other contexts of Sino-African cooperation, but represent a more significant challenge to communication in non-English speaking countries such as Mozambique and Angola (Corkin 2012).

\section{Material support issues}

Low wages are a constant complaint amongst the Mozambican workers. The payment they receive is at or below minimum wage, and below what the workers would deem a fair wage. 
While wages in Mozambique are often half of the wages of equivalent industries in neighbouring countries because of the country's low technical efficiency (Castel-Branco 2001), Chinese companies are infamous for paying the lowest wages in the Mozambican construction industry (Nielsen 2014). For the Chinese workers, however, work in an African country signifies better payment than employment in China and their salary is significantly better than that of their Mozambican colleagues (Interview, Chinese project manager and engineers, 30.05, 19.06, and 22.08.13). Higher wages for Chinese workers is common elsewhere, such as in the Angolan construction industry, where Tang (2010) found that on average, Chinese workers earned 60 percent more than their Angolan colleagues. Furthermore, the Mozambican workers do not know their daily working schedule. While they have a set arrival time, the finishing hour is not fixed. As a result, they do not know how much they are supposed to earn:

Overtime here? They say they have overtime, but how should we know how to handle it, we are badly informed! You work Saturdays and Sunday, you leave late in the middle of the week, and you just write... but it is they [the Chinese] who handle this, we are not present to see exactly what is paid [...] No I don't know what criteria they use. (Group interview 2, Mozambican workers, 17.05.13)

In Mozambique, there are set limits to the number of hours in a working day or week, with a maximum of eight-hour working day and 48-hour week as the general rule. Moreover, the labour law strictly regulates overtime, limited to eight hours per week and includes a mandatory rest day (ACIS 2011). In the Sino-Mozambican workplaces, the contracts are in line with legislative requirements, but, in practice, employees generally work longer hours and the company has added Sundays as part of the working week. A study of 54 Chinese factories found that the use of such compulsory overtime is common in China (Chan and Xiaoyang 2003). According to the findings of Corkin (2012) in Angola, the Chinese modus operandi is to work until they reach the target of the day, not a certain amount of hours before leaving or receiving overtime. This way of organising the workday has apparently been transferred to both Mozambique and Angola, and is on a collision course with national regulations and Mozambican workers' expectations. The discrepancy between workers' hours according to their contracts, and the actual hours worked arises in part because of the Mozambican government's limited capacity to enforce labour regulations. 
In terms of non-main wage material support, the division between the Chinese and the Mozambican workers is sharp. Chinese workers receive food, housing and medical care. Some of the Mozambican workers receive small subsidies for food and transportation of about 100 MTN per month (approximately 3,4 USD), but the subsidies do not cover workers' actual costs (Group interview, Mozambican workers, 20.05.13, copy of worker's pay check 30.04.2013). The Chinese workers have their own cook and doctor at the project site. Neither may be used by Mozambican workers. Should the Mozambicans get sick or injured they would be taken to the public hospital, and the company often deducts medical bills from their pay. The Mozambican workers are very much aware of these divisions, which exacerbate the feeling of being unfairly treated:

They have their own food and, you know, they are not even sharing with the ones who are working with them. And us who don't even receive subsidies for food, in areas where there are nowhere to buy food, we have to bring from home. (Interview Mozambican worker 17.05.13).

They put on their raincoats and hide underneath the trucks while we are standing in the rain. (Group interview 1, Mozambican workers 17.05.13).

Complaints about material issues are well-documented in the literature on Chinese labour practices in Africa. The African Labour Research Network (ALRN 2009, 13) reports 'tense labour relations, hostile attitudes by Chinese employers towards trade unions, violations of workers' rights, poor working conditions and unfair labour practices', and results from various case studies in other African countries support these findings (see, e.g., Afrodad 2008; Baah and Jauch 2009; Lee 2009; HRW 2011).

\section{Contract issues}

The percentage of Mozambican workers with contracts varies amongst the three projects. Nearly all the workers have written contracts in the first project, a minority of the workers have contracts in the second, and in the third, none of the workers have contracts. However, the contract does not have any effect on work security, work tasks or status. Even workers with contracts know that their superior can fire them for any reason at any time, signifying that the contract is nothing more than a formality: 
No one knows the day to leave, but the contract is the same, because every day when you come to work, you may find a list and see that you're no longer going to work. [Mimics the superiors] 'You do not work, you do not come anymore, go home, go home', just because your boss does not like you. (Group interview 1, Mozambican workers, 17.05.13).

Literature on national Chinese projects reveals that construction workers in China seldom hold written contracts or have access to social security benefits. The workers often live on small allowances that should cover daily costs, while salaries are paid annually (Tang 2014). Chinese workers are paid using a similar arrangement in Chinese-led projects in Mozambique. However, the Mozambican workers' perception is that the Chinese never have to spend any money because they are taken care of by the company. Moreover, Chinese workers tended to have a safe position with the company, and most of them had worked for the company for 5 to 15 years. Although they seldom have a choice in deciding what country to work in, many engineers regarded employment in Africa as a great opportunity. The sector is crowded and competitive in China, and a job in an African country signifies more money, more experience, and a steeper learning curve (Interviews, Chinese engineers, 30.05, 13.06, 19.06, and 22.08.13).

The strong divisions between the two nationalities that permeate the workplace lead to the cementing of two separate workplace regimes. While Mozambican workers complain about equipment, wages and lack of job security, this case illustrates that the divided workplace, where different workers are subject to different workplace regimes, is an underlying cause of resentment and tension in the Sino-Mozambican. Although Mozambican workers may be used to poor pay and working conditions in Mozambican companies, the lack of a social relationship and the constant reminders of segregation seem to be exacerbating the workers' grievances. So why do they stay on the project?

\section{Labour agency in a divided workplace}

Labour agency is affected both by the organisation of the workplace and the wider institutional framework, and may entail both individual and collective strategies (Coe and Jordhus-Lier 2011). In this context, labour agency is examined by looking at the strategies the workers use as responses to the workplace regime they take part in. 


\section{Voicing resentment}

The Mozambican workers explain how they employ two voice strategies to demonstrate their resentment as a group. The first is what they refer to as strike, similar to the one mentioned in the introduction. Such strikes occur on a regular basis and normally continue for one or two days. Workers sit outside the project area refusing to work. However, they return to work before any agreement is reached, often without any negotiation, because they cannot afford to lose more than a few days' pay (Interview, Mozambican workers, 17.05.13, 16.01.14, 01.10.14). The workers think of their actions as part of an ongoing strike or struggle, even when they return to work:

We continue to work, but the strike will go on until they [the Chinese company] change a bit. What we want is that they give us money so that we are able to work every day, but also that they give us time because we have families. (Interview, Mozambican workers, 16.01.14)

A second response has been 'shutdowns' (paralisaçoes) initiated by drivers. They stop their cars for up to two hours during the day to demonstrate against the unfair company policy where workers are responsible for equipment (including cars) that is damaged during their shift. Neither of these strategies have resulted in any significant change on behalf of the company although some of the workers mentioned that they believe the day-to-day pressure from their Chinese superiors has decreased slightly. Workers' pay checks, contract, and hours have stayed the same, and the cost of broken equipment is still withdrawn from their pay check. These strategies can be deemed collective, simply because they entail a certain collective organisation. However, the strategies fail to accomplish any change in the workplace regime because of their ad hoc nature and lack of institutional support and political scale. Trade unions do not organise the shutdowns or strikes, and may not even be involved until the Ministry of Labour prompts the unions to intervene and resolve an ongoing strike.

Mozambique has around 21 unions, grouped into two official federations; the OTM and CONSLIMO. The trade union that organises construction workers falls under the latter. While Mozambican trade unions operate independently, their strength has gradually weakened. Companies routinely ignore minimum wage laws and the unions have few sanctioning mechanisms for companies that do not comply with labour regulations (Webster and Wood 2005, Dibben and Williams 2012). Both the trade union and the Ministry of 
Labour are aware of the conditions in the Sino-Mozambican projects and violations of Mozambican law and regulations by Chinese companies. However, they have not been able resolve the situation, and Mozambican workers have little confidence in the ability of any external agent to improve their situation: 'Now when it comes to the union, they practically do not exist' (Group interview, Mozambican workers 16.01.14). According to workers in one of the projects, they unionised in the early phases of the project and had elected representatives. However, after several rounds of negotiations with the Chinese company where their requirements were not met, the representatives felt that their image was being tarnished, and that the other workers would see them as traitors if they continued to associate with the union (Interview, Mozambican worker, 01.10.14). The union blames the situation on problematic cooperation with Ministry of Labour. Instead of being included in the process when new businesses establish themselves in the construction sector, the union is involved only when problems occur:

There are companies that have been working in Mozambique for four to five years, just that we only get to know them when there are problems [...]. When already in a strike, we often find that the workers say 'you say you are the union, but where have you been during these four years when we have been here suffering every day? [...]Please leave; we will solve this ourselves.' I mean, we are in a difficult situation. Who contributes, however, is the government itself. (Interview, trade union, 14.06.13)

The interview excerpt above illustrates some of the challenges facing the union. Unions are dependent on cooperation from the government that they do not receive, and on recognition from the workers that they do not have. The unions, therefore, do not enable workers' agency as they lack bargaining power and sanctioning authority. This is in line with the findings of Webster et al. (2006). They explain that the Mozambican labour movement was initially designed as a 'transmission belt for ruling party decisions' (258) with real power located in the workplace. Economic reforms during the 1990s broke the unions' close relation with the ruling party and weakened the unions' bargaining position.

The collective responses of the Mozambican workers can be categorised as voice strategies aimed at improving working conditions. However, workers' intentions are not achieved, illustrating the need to distinguish between the intention of workers' strategies and what they actually accomplish (Coe and Jordhus-Lier 2011). In the Sino-Mozambican workplace, the lack of institutional support constrains the potential scale of workers' strategies and the 
potential for these strategies to result in negotiations and change. Negotiations are not brought to a level with decisive power, and the Chinese companies are not pressured into meeting the demands of the workers. The workers' collective strategies can be viewed as agency in that the workers use them to alter the workplace. However, they do not successfully achieve this goal.

\section{Lack of commitment and the exit option}

Lacking institutional support, workers may turn to individual strategies. Low job satisfaction is predicted to lead to the less fruitful responses of neglect or exit (Farrell and Rusbult 1992). While many workers express a wish to quit, the tough labour market conditions prevent them from pursuing this option. According to the African Development Bank (2012), 27 percent of the Mozambican population is unemployed, and an estimated 300000 new workers enter the labour market annually. Furthermore, the formal sector accounts for only 32 percent of all employment in the country. As expressed by one of the workers:

[...] here in Mozambique, to find work is a serious problem, if you find one, you have to work. To get work in Mozambique is no joke; you have to endure the conditions. (Group interview, Mozambican workers, 17.05.13)

Although employment generation, decent work, and formalisation of labour is a top priority for the Mozambican government in national development strategy papers (e.g., PRP 20112014, IMF 2011), the government has so far failed to establish appropriate support mechanisms to fulfil these goals. While workers have the intention to exit, the lack of alternatives inhibits their actions. The line of job-seeking young men outside the construction sites is a reminder of the constant threat of replacement. The Mozambican workers both feel themselves to be and in fact are replaceable, especially since they mainly execute low-skilled work tasks. The high level of unemployment and the large informal employment sector intensifies the situation and results in advantages for Chinese companies. A Chinese engineer formulated it simply when asked about the qualities of local labour: 'The good thing is that they are easy to find, the workers. Because many, many people do not have formal jobs'. (Interview, 27.05.13).

According to Farrell and Rusbult (1992), a lack of job alternatives may lead to the passive responses of loyalty or neglect. The Sino-Mozambican workplace regime does not provide 
space for loyalty, but there are elements of neglect amongst the workers. Some workers choose not to participate in the strikes, as they are demoralised after several attempts with little or no positive change. Such a response is consistent with findings from Lee's (2009) fieldwork in Tanzania, where repeated unsuccessful strikes amongst the workers have led to workers passively accepting deteriorating employment conditions. In the Sino-Mozambican workplaces, neglect is especially visible in Mozambican workers' lack of commitment:

With their behaviour, it is no one who dreams of leaving here to go to another Chinese company. (Interview 1, Mozambican workers, 17.05.13)

The day a better job appears for me, I will disappear. (Interview, Mozambican workers, 03.06.13)

No one is here because they want to be here, it is because they have nowhere else to go ... no one can say that those who are here are already well, you are only here because you still haven't found a job... if I had, I wouldn't be here. (Interview 2, Mozambican workers, 17.05.13)

Workers' lack of commitment relates to several of features of the workplace regimes outlined above. First, it is connected to the companies' use of functional flexibility, where the workers feel they have no individual value in the workplace and are only doing simple, heavy work. Furthermore, workers' lack of commitment relates to payment. The workers do not feel appreciated, as the material support received is very low despite the fact that they work longer hours and the workload is heavier than in other local jobs. Lastly, the lack of commitment relates to lack of communication and the strict separation of Chinese and Mozambican workers, which hampers the potential for creating personal relationships between nationalities. Combined with little determination over their own job and the future, the Mozambican workers have a hard time finding any commitment to the project or the company.

The strategies pursued by Mozambican labour have not resulted in any change to the system's status quo. As long as their voice strategies are not successful, the only potential for workers to actively alter their own situation seems to be exit. This is not necessarily a problem for the Chinese companies as long as they have an abundant pool of labour from which to recruit new workers. Furthermore, individual exit is dependent on alternative jobs in the local labour market. Otherwise, the workers will stay. The local labour market provides 
few alternatives, meaning that although the majority of the Mozambican workers are miserable in their current situation, they are prevented from choosing exit. In sum, labour agency is constrained at three levels. First, the degree of distance between Chinese and Mozambicans in the workplace leaves little space for participation and beneficial voice strategies. Second, workers lack institutional support to respond to company violations of their rights and labour regulations. Third, workers lack alternative employment opportunities in the local labour market.

\section{Conclusion}

In 2007, China's Vice-minister of Commerce stated that 'the new type of strategic partnership between China and Africa is characterized by equality, mutual benefit, and economic win-win cooperation. ${ }^{8}$ Situated at the bottom of the hierarchy in this relationship, the Mozambican workers find it hard to recognize their own situation within that description:

When he [President Guebuza] laid the foundation stone for the [project], he said it was part of the fight against poverty. But what we are doing here is a misery to our children and our brothers. (Interview, Mozambican worker, 17.05.2013)

The grievances described in studies of Chinese business practices in other African countries, such as low pay, work insecurity, and poor working conditions, are also present in SinoMozambican workplaces. Further, this study shows that the divisions between two workplace regimes, one for the Chinese and one for the Mozambicans, exacerbates the level of tension and resentment in the workplace. Such divisions are recognized in other cases, but seldom given explanatory power. I argue that the 'divided workplace', where different workers are subject to different workplace regimes, is one of the main contributors to resentment and tension. The Mozambican workplace regime is traditionally not one of high pay, social benefits, or training schemes, but positive informal relationships between employers and employees seem to be compensating for this. This social relationship is lacking in the SinoMozambican workplace, where divisions between Chinese and Mozambican workers are pervasive. As long as Chinese companies continue to isolate themselves and their workers from the societies in which they operate, socio-cultural misunderstandings are bound to be perpetuated. Moreover, the lack of a common language does not just challenge verbal communication, but several additional elements end up 'lost in translation'. While similar divisions characterize other multicultural work environments, the language barrier, the 
foreignness of the Chinese in the Mozambican society, and the weak institutional framework in Mozambique makes these divisions more pronounced in the Sino-Mozambican workplace. Although both the macro-level politics of the state and the micro-level of politics in the workplace shape workplace regimes, the latter seems more important in this context, given the freedom granted Chinese contractors in the construction industry in Mozambique.

Complete workplace regimes cannot be exported, and certain elements may originate in one context, but be completely transformed in a new context. The Sino-Mozambican workplace includes the dormitory practice of Chinese workplaces, but dormitories are given new meaning beyond that of control. Rather, the company administration stresses the need to stimulate togetherness and socialisation amongst the Chinese workers in a foreign environment. While control cannot be excluded as a motivation for using dormitories in Mozambique, the Mozambican workers are excepted from this practice. The reason seems to be that the Chinese companies are not responsible for Mozambican labour, and thus do not need to control Mozambican workers outside the workplace. Control mechanisms are, however, quite clear in the organisation of work tasks. Moreover, elements such as a lack of contract and extensive use of overtime appear similar to practices of Chinese companies in China.

Mozambican workers find themselves locked in their current work situation, with their agency heavily constrained. The workplace does not provide constructive space for participation and voice strategies because of the degree of distance between Chinese and Mozambicans. Moreover, the workers lack institutional support to respond to company violations of their rights and regulations. The workers' collective strategies illustrate the difficulties in accomplishing their objectives when negotiations lack institutional support that could provide political scale. In addition, the workers are prevented from exiting because of the lack of alternative employment opportunities in the local labour market.

While labour is in theory protected and regulated through the Constitution and Labour Law, this does not translate into labour protection in practice. This study illustrates the challenges of a development strategy that relies on foreign capital but lacks the institutional capacity to monitor and control whether foreign activities are in line with national law and regulations. Economic concerns continue to dominate Mozambican industrial policy, and as noted by Levy $(2003,4)$, 'the gap between the theory as announced in the law and practice in the labor market is very great.' 


\section{References}

AFDB (African Development Bank). 2012. Mozambique. Retrieved from: http://www.afdb.org/fileadmin/uploads/afdb/Documents/Publications/Mozambique\%20Full\% 20PDF\%20Country\%20Note.pdf

AFRODAD (African Forum and Network on Debt and Development). 2008. Mapping Chinese Development Assistance in Africa. Harare: AFRODAD.

ALRN (African Labour Research Network). 2009. Chinese Investments in Africa: Opportunity or Threat for Workers? Retrieved from: http://www.worldlabour.org/eng/node/243

Alden, C., Chichava, S., and Roque, P. C. 2014. "China in Mozambique: Caution, Compromise and Collaboration." In China and Mozambique: From Comrades to Capitalists, edited by C. Alden and S. Chichava, Sunnyside, South Africa: Fanele.Alden, C., and Davies, M. 2006. "A Profile of the Operations of Chinese Multinationals in Africa." South African Journal of International Affairs 13(1): 83-96.

ACIS (Associacão de Comércio e Indústria). 2011. The Legal Framework for Employment and Immigration in Mozambique. ACIS.

Anderson, E.J. 2012. "What does Hydrocarbon Wealth mean for Foreign Aid in Mozmabique?" SAIIA Policy Breif, 50, Global Powers and Africa Programme.

Baah, A.Y., and Jauch, H. 2009. "Chinese Investments in Africa." In Chinese Investments in Africa: A Labour Perspective, edited by In A.Y. Baah and H. Jauch, 35-76. African Labour Reserach Network.

Blecher, M. 2010. "Globalization, Structural Reform, and Labour Politics in China". Global Labour Journal 1(1): 90-111.

Braütigam, D. 2008. "'Flying Geese' or 'Hidden Dragon': Chinese Business and African Industrial Development". In China Returns to Africa: A Rising Power and a Continent Embrace, edited by Large, D., Alden, J.C. and Soares de Oliveira, R., London: Christopher.

Bray, D. 2005. Social Space and Governance in Urban China: The Danwei System from Origins to Reform. Stanford: Stanford University Press.

Burawoy, M. 1985. The Politics of Production: Factory Regimes under Capitalism and Socialism. London: Verso.

Carswell, G. and de Neve, G. 2013. "Labouring for Global Markets: Conceptualising Labour Agency in Global Production Networks." Geoforum, no. 44: 62-70.

Castel-Branco, C. N. 2001. An Investigation into the Political Economy of Industrial Policy: the Case of Mozambique. Ph.D. diss., University of London. Retrieved from: http://www.iese.ac.mz/? target =investigator\&investigatorid=1

Castree, N., Coe, N.M., Ward, K and Samers, M. 2004. Spaces of Work: Global capitalism and Geographies of Labour. London: Sage

CCS (Centre for Chinese Studies). 2006. China's Interest and Activity in Africa's Construction and Infrastructure Sectors. Stellenbosch: University of Stellenbosch.

Chan, A., and Xiaoyang, Z. 2003. "Disciplinary Labor Regimes in Chinese Factories." Critical Asian Studies 35(4): 559-584.

Coe, N. M., and Jordhus-Lier, D. C. 2011. "Constrained Agency? Re-evaluating the Geographies of Labour." Progress in Human Geography 35(2): 211-233.

Corkin, L. 2012. "Chinese Construction Companies in Angola: A Local Linkages Perspective." Resources Policy 37 (4): 475-483.

Cottle, E. 2014. "Chinese Construction Companies in Africa: A Challenge for Trade Unions." Global Labour Column, 179. Retrieved from: http://column.global-labouruniversity.org/2014/07/chinese-construction-companies-in.html

Cumbers, A., Nativel, C., and Routledge, P. 2008. "Labour Agency and Union Positionalities in Global Production Networks." Journal of Economic Geography 8(3): 369-387. doi: 10.1093/jeg/lbn008

Dibben, P. and Williams, C.C. 2012. "Varieties of Capitalism and Employment Relations: Informally Dominated Market Economies.” Industrial Relations 51( S1): 563-582. 
Dokka, S., Knutsen, H.M and Endresen, S.B. 2015. "Outsourcing with a Human Face? Variegated Workplace Regimes in the Norwegian Hotel Industry". In A Hospitable World? Organising Work and Workers in Hotels and Tourist Resorts, edited by D. Jordhus-Lier and A. Underthun, 84-100. Oxon: Routledge.

Dyer, S. 1998. "Flexibility models: a critical analysis." International Journal of Manpower 19 (4): $223-233$.

Farrell, D. 1983. "Exit, Voice, Loyalty, and Neglect as Responses to Job Dissatisfaction: A Multidimensional Scaling Study.” The Academy of Management Journal 26 (4): 596-607.

Farrell, D., and Rusbult, C.E. 1992. "Exploring the Exit, Voice, Loyalty, and Neglect Typology: The Influence of Job Satisfaction, Quality of Alternatives, and Investment Size." Employee Responsibilities and Rights Journal 5(3): 201-218.

Giese, K. and Thiel, A. 2012. "The Vulnerable Other - Distorted Equity in Chinese-Ghanaian Employment Relations." Ethnic and Racial Studies 37 (6): 1101-1120.

Herod, A. 2001. Labor Geographies. Workers and the Landscape of Capitalism. New York: The Guilford Press.

Hirschman, A.O. 1970. Exit, Voice, and Loyalty: Responses to Decline in Firms, Organizations, and States. Harvard: Harvard university press.

HRW (Human Rights Watch). 2011. "You'll Be Fired if You Refuse" Labor Abuses in Zambia's Chinese State-owned Copper Mines. New York: HRW.

International Monetary Fund. 2011. Republic of Mozambique: Poverty Reduction Strategy Paper. IMF Country Report. Maputo: IMF.

Knutsen, H.M., and Hansson, E. 2010. "Theoretical Approaches to Changing Labour Regimes in Transition Economies." In Missing Links in Labour Geography, edited by Bergene, A.C., Endresen, S.B. and Knutsen, H.M., 155-169. Farnham: Ashgate.

Kragelund, P. 2009. "Knocking on a wide-open door: Chinese investments in Africa." Review of African Political Economy 36(122): 479-497.

Lee, C.K. 1999. "From organized dependence to disorganized despotism: Changing labour regimes in Chinese factories." The China Quarterly, no. 157: 44-71.

Lee, C.K. 2009. "Raw Encounters: Chinese Managers, African Workers and the Politics of Casualization in Africa's Chinese Enclaves." The China Quarterly, no. 199: 647-666. doi: doi:10.1017/S0305741009990142

Lee, M. C. 2006. "The 21st century scramble for Africa." Journal of Contemporary African Studies, 24(3), 303-330.

Levy, S. 2003. The legal and administrative framwork for labor relations in Mozambique. Maputo: SAL Consultoria e Investimentos, Lda.

Magnusson, O.A., Knutsen, H.M., and Endresen, S.B. 2010. "Between coercion and consent: Understanding post-Apartheid workplace regimes." In Missing Links in Labour Geography, edited by Bergene, A.C., Endresen, S.B. and Knutsen, H.M., 169-181. Surrey: Ashgate.

Meidan, M. 2006. "China's Africa policy: business now, politics later." Asian Perspective 30(4): 6993.

Mohan, G., and Lampert, B. 2013. "Negotiating China: Reinserting African Agency into ChinaAfrica Relations." African Affairs 112(446): 92-110.

Mohan, G., and Power, M. 2009. "Africa, China and the 'new' economic geography of development." Singapore Journal of Tropical Geography 30(1): 24-28. doi: 10.1111/j.14679493.2008.00352.x

Ngai, P. and Huilin, L. 2010. "A Culture of Violence: The Labour Subconracting System and Collective Action by Construction Workers in Post-socialist China." The China Journal, no. 64: 143-158.

Nichols, T., Cam, S., Chou, W.-c. G., Chun, S., Zhao, W., and Feng, T. 2004. "Factory regimes and the dismantling of established labour in Asia: a review of cases from large manufacturing plants in China, South Korea and Taiwan." Work, Employment \& Society 18(4): 663-685. doi: 10.1177/0950017004047958

Nielsen, M. 2014. "How not to build a road: An analysis of the socio-economic effects of a Chinese infrastructure project in Mozambique." In China and Mozambique: From comrades to capitalists, edited by Alden, C. and Chichava, S., 67-83. Auckland Park: Fanele. 
Peck, J. 1996. Work-place: The social regulation of labor markets. New York: Guilford Press.

Pun, N. and Smith, C. 2007. "Putting transnational labour process in its place the dormitory labour regime in post-socialist China." Work, Employment \& Society 21(1): 27-45.

Pun, N., and Yu, X. 2008. "When Wal-Mart and the Chinese dormitory labour regime meet: a study of three toy factories in China." China Journal of Social Work 1(2): 110-129. doi: $10.1080 / 17525090802086356$

Robertson, C., and Corkin, L. 2011. "China in Africa." Strategies EMEA, Update Economics and Strategy research, 21 April 2011, Renaissance Capital. Retrieved from: http://www.fastestbillion.com/res/Research/China_in_Africa-210411.pdf

Robinson, D. 2012. "Chinese engagement with Africa: The Case of Mozambique." Portuguese Journal of International Affairs, 6 (summer/spring 2012), 1-15.Rogaly, B. 2009. "Spaces of Work and Everyday Life: Labour Geographies and the Agency of Unorganised Temporary Migrant Workers." Geography Compass 3(6): 1975-1987.

Rusbult, C.E., Farrell, D., Rogers, G., and Mainous III, A.G. 1988. "Impact of Exchange Variables on Exit, Voice, Loyalty, and Neglect: An Integrative Model of Responses to Declining Job Satisfaction." The Academy of Management Journal 31(3): 599-627. doi: 10.2307/256461

Tang N. 2014. "Migrant Workers' Educational Mismatch and the abour Market in China." UCLA Institute for Research on Labor and Employment. Working Paper no. 10.

Tang, X. 2010. "Bulldozer or Locomotive? The impact of Chinese Enterprises on the Local Employment in Angola and the DRC." Journal of Asian and African Studies 45(3): 350-368.

Thagaard, T. 2009. Systematikk og innlevelse. Bergen: Fagbokforlaget.

Vines, A. 2007. "China in Africa: a mixed blessing?" Current history 106(700): 213-219.

Wang, C., and Flam, D. 2007. "Bridging the gap: Experiences and attitudes in Sino-African relations." China Rights Forum, no.2: 196-208.

Webster, E., and Wood, G. 2005. "Human Resource Management Practice and Institutional Constraints: The Case of Mozambique." Employee Relations 27(4): 369-385.

Webster, E., Wood, G, and Brookes, M. 2006 "International Homogenization or the Persistence of National Practices? The Remaking of Industrial Relations in Mozambique." Industrial Relations 61(2): 247-270

Webster, E., Wood, G., Mtyingizana, B., and Brookes, M. 2006. "Residual Unionism and Renewal: Organized Labour in Mozambique." Journal of industrial relations 48(2): 257-278.

Wethal, U. 2015. "Searching for sustainability in Mozambique's development strategy." In Emerging economies and challenges to sustainability: theories, strategies, local realities, edited by Hansen, A. and Wethal, U., 218-233. Oxon: Routledge.

Wood, G. 2011. "Employment relations in South Africa and Mozambique." In Research Handbook of Comparative Employment Relations, edited by Barry, M. and Wilkinson, A., 303-321. Cheltenham: Edward Elgar.

\footnotetext{
${ }^{1}$ http://allafrica.com/stories/201401071365.html (accessed 08.01.2014).

${ }^{2}$ I have translated all citations from Portuguese, except interviews with Chinese informants and relevant international organisations that were performed in English. I have made some grammatical changes to the citations in order to clarify the meaning, without altering the content.

${ }^{3} \mathrm{http} / / / \mathrm{www}$.iaffairscanada.com/2016/how-africa-will-solve-the-chinese-construction-crisis (accessed 10.12.2016)

${ }^{4}$ From 2009-2011, China was on of the top 5-6 investors in Mozambique according to numbers from the Investment Promotion Centre (CPI) in Maputo. However, with the exploration of gas, coal and minerals in the North, large international players such as Italian ENI, American Anadarko and Brazilian Vale are dominating investments (Anderson 2012).

${ }^{5}$ The data collected in 2013 was supplemented by interviews performed by research assistant Sérgio Cossa during 2014.

${ }^{6}$ I was not allowed to tape the interviews with Chinese company administration.

${ }^{7}$ The survey covered 177 companies in greater Maputo and greater Beira (the second centre for industrial and commercial activity in Mozambique).

${ }^{8}$ http://news.xinhuanet.com/english/2007-02/05/content_5700395.htm (accessed 17.04.2013).
} 